\title{
KEY PERFORMANCE INDICATOR (KPI) DESIGN OF BAMBOO CREATIVE INDUSTRY IN GODEAN SLEMAN DISTRICT AREA
}

\author{
Yasrin Zabidi \\ Program Studi Teknik Industri Sekolah Tinggi Teknologi Adisutjipto \\ Jl. Janti Blok R Lanud Adisutjipto Yogyakarta \\ Email : yazma_2000@yahoo.com
}

\begin{abstract}
Performance issues are not only important for upper middle and large companies, but also important for Small and Medium Industries Creative Industries. To evaluate the current condition of a creative industry, the creative industry needs to determine the multi-criteria Key Performance Indicator (KPI) properly and correctly. Therefore in this study, researchers tried to design a Key Performance Indicator (KPI) for the creative industries of bamboo crafts in the Godean district of Sleman. The design of KPI uses the Balanced Scorecard method which includes setting strategic objectives, determining key performance indicators (KPI). From the results of the study obtained $10 \mathrm{KPI}$, namely: the level of sales growth, the level of customer growth, the level of customer satisfaction, the level of customer complaint fulfillment, the level of production speed, the number of products produced by labor, the percentage of defective products, the percentage of the level of effort to repair defective products, the level of productivity employees, and employee job satisfaction
\end{abstract}

Keywords: Performance, Performance Indicator, Key Performance Indicator (KPI), Balanced Scorecard, Creative Industry.

\section{Pendahuluan}

Industri kreatif telah banyak berkembang di wilayah Daerah Istimewa Yogyakarta, salah satunya di daerah Kecamatan Godean, Kabupaten Sleman. Godean merupakan salah satu sentra industri kreatif kerajinan bambu yang berada di Kabupaten Sleman. Industri kreatif kerajinan bambu pada dasarnya merupakan kategori industri manufaktur yang memproses input menjadi output (produk/barang).

Salah satu faktor yang penting dalam mempengaruhi proses kemajuan dan kemunduran suatu industri adalah faktor kinerja, artinya meningkatkan kinerja berarti meningkatkan kesejahteraan dan mutu perusahaan. Masalah kinerja bukan hanya penting bagi perusahaan menengah ke atas maupun perusahaan besar, tetapi juga penting bagi Usaha Kecil Mengengah (UKM) seperti industri kreatif kerajinan bambu di wilayah Godean Sleman. Kelancaran proses bisnis dan kemajuan usaha tidak terlepas dari peran kinerja itu sendiri. Tanpa kinerja maka matilah proses bisnis tersebut.

Industri kreatif yang merupakan salah satu bentuk kegiatan bisnis yang berada pada suatu wilayah/daerah yang memiliki peran sangat penting bagi berlangsungnya perekonomian daerah, kesejahteran masyarakat. Untuk mengevaluasi kondisi suatu industri kreatif pada saat ini, maka industri kreatif tersebut perlu untuk menentukan Key Performance Indicator (KPI) secara baik dan benar karena ukuran kinerja ini dapat dijadikan sebagai bahan pertimbangan dan penambahan fasilitas produksi dan tenaga kerja yang akan mendukung aktivitas perusahaan.

Oleh karena itu pada penelitian ini, peneliti mencoba untuk mendesain Indikator kinerja (Key Performance Indicators) industri kreatif kerajinan bambu di wilayah kecamatan Godean, Sleman. 


\section{Metodologi Penelitian}

Langkah-langkah dalam penelitian ini terbagi atas empat fase, yaitu : fase penelitian awal dan perumusan masalah, fase perancangan, fase analisis dan fase kesimpulan. Fase penelitian awal dan perumusan masalah meliputi, profil industri kreatif kerajinan bambu di wilayah kecamatan Godean Sleman, sistem evaluasi kinerja saat ini, perumusan masalah dan penentuan tujuan penelitian. Fase desain meliputi proses perancangan KPI dengan metode Balanced Scorecard yang meliputi penetapan arsitektur yang terdiri atas visi, misi, penetapan tujuan strategik, penetapan idikator-indikator kinerja (key performance indicator). Fase analisis meliputi analisis KPI dan analisis peta strategi. Fase kesimpulan meliputi kesimpulan dari hasil penelitian serta saran-saran bagi industri kreatif kerajinan bambu di wilayah kecamatan Godean Sleman dan kelanjutan penelitian ini. Adapun kerangka pemecahan penelitian ini dapat dilihat dalam gambar 1. langkah-langkah penelitian.

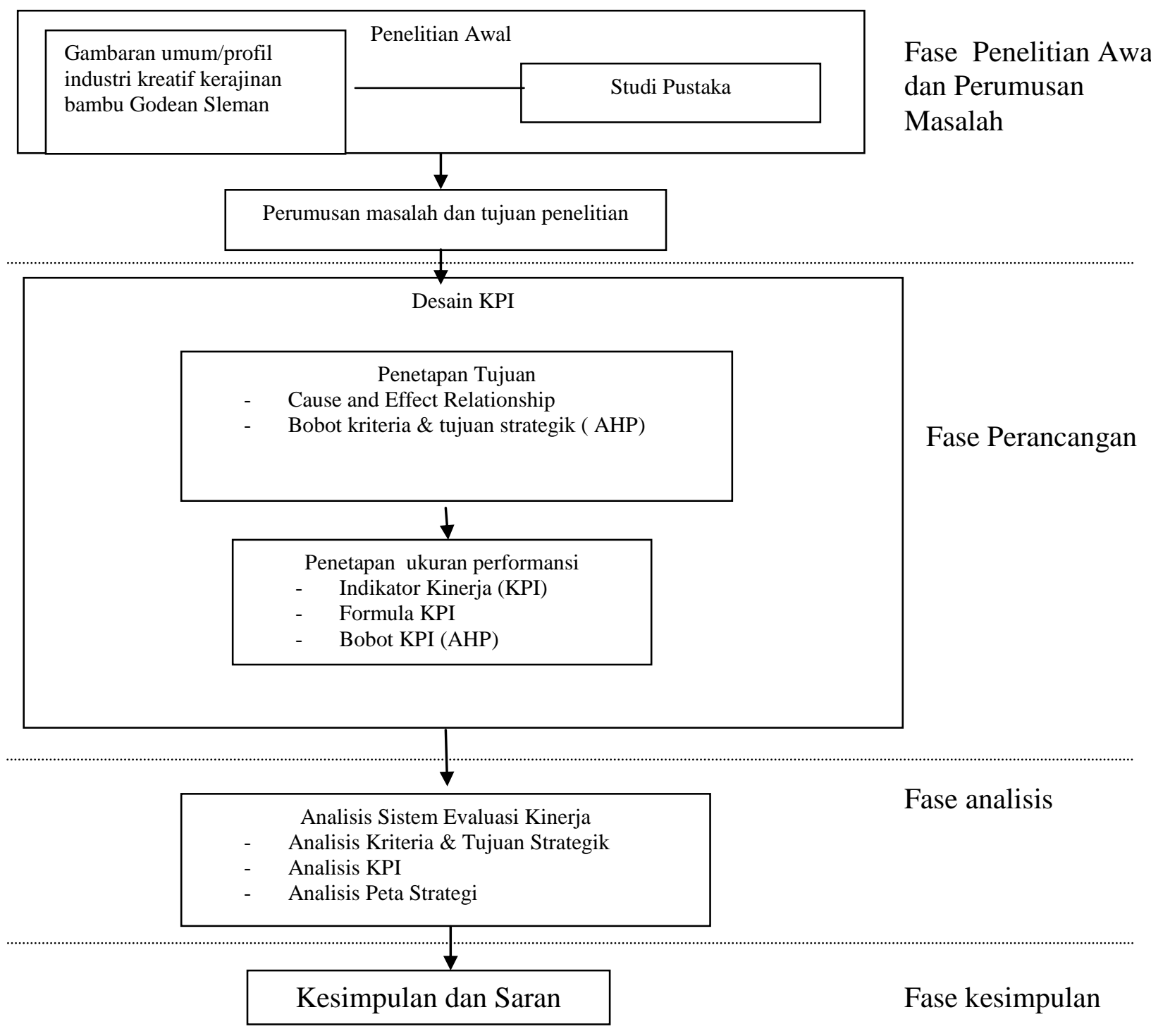

Gambar 1. Langkah-langkah Penelitian 


\section{Hasil dan Pembahasan}

\subsection{Kriteria Kinerja dan Bobot Kepentingan}

Ada 4 kriteria kinerja yang digunakan dalam penelitian ini, yaitu:

1. Finansial

2. Konsumen

3. Proses Bisnis Internal

4. Belajar dan tumbuh

Tabel 1. Kriteria Kinerja dan Bobot Kepentingan

\begin{tabular}{|c|l|c|}
\hline No & \multicolumn{1}{|c|}{ Kriteria } & Bobot \\
\hline 1 & Kriteria Finansial & 0,395 \\
\hline 2 & Kriteria Konsumen & 0,232 \\
\hline 3 & Kriteria Proses Bisnis Internal & 0,232 \\
\hline 4 & Kriteria Belajar dan Tumbuh & 0,140 \\
\hline
\end{tabular}

\subsection{Tujuan Stategis}

Tabel 2. Tujuan-Tujuan Strategis

\begin{tabular}{|c|l|l|}
\hline \multicolumn{1}{|c|}{ No } & \multicolumn{1}{|c|}{ Kriteria } & \multicolumn{2}{|c|}{ Tujuan-Tujuan Strategis } \\
\hline 1 & Finansial & $\begin{array}{l}\text { 1. Pertumbuhan penjualan yang } \\
\text { meningkat }\end{array}$ \\
\hline 2 & Pelanggan & $\begin{array}{l}\text { 1. Pertumbuhan pelanggan yang tinggi } \\
\text { 2. Kepuasan pelanggan yang tinggi }\end{array}$ \\
\hline 3 & $\begin{array}{l}\text { Proses Bisnis } \\
\text { Internal }\end{array}$ & $\begin{array}{l}\text { 1. Peningkatan produktivitas } \\
\text { 2. Peningkatan kualitas produk }\end{array}$ \\
\hline 4 & $\begin{array}{l}\text { Belajar dan } \\
\text { Pertumbuhan }\end{array}$ & $\begin{array}{l}\text { 1. Produktivitas karyawan yang } \\
\text { meningkat } \\
\text { Terciptanya iklim kerja yang baik }\end{array}$ \\
\hline
\end{tabular}

\subsection{Bobot Kepentingan Tujuan Strategis}

Tabel 3. Bobot Derajat Kepentingan Tujuan-Tujuan Strategis

\begin{tabular}{|c|l|c|}
\hline \multicolumn{1}{|c|}{ No } & \multicolumn{1}{|c|}{ Tujuan Strategis } & Bobot \\
\hline 1 & Pertumbuhan penjualan yang mengingkat & 0,395 \\
\hline 2 & Pertumbuhan pelanggan yang tinggi & 0,116 \\
\hline 3 & Kepuasan pelanggan yang tinggi & 0116 \\
\hline 4 & Peningkatan produktivitas & 0,116 \\
\hline 5 & Peningkatan kualitas produk & 0,116 \\
\hline 6 & Produktivitas karyawan yang meningkat & 0,070 \\
\hline 7 & Terciptanya iklim kerja yang baik & 0,070 \\
\hline
\end{tabular}




\subsection{Key Performance Indicator (KPI)}

Tabel 4. Key Performance Indicator (KPI)

\begin{tabular}{|c|c|}
\hline Kriteria & Key Performance Indicators \\
\hline KRITERIA FINANSIAL & a. Tingkat pertumbuhan penjualan \\
\hline KRITERIA PELANGGAN & $\begin{array}{l}\text { a. Tingkat pertumbuhan pelanggan } \\
\text { b. Tingkat kepuasan pelanggan } \\
\text { c. Tingkat pemenuhan keluhan pelanggan }\end{array}$ \\
\hline $\begin{array}{l}\text { KRITERIA PROSES BISNIS } \\
\text { INTERNAL }\end{array}$ & $\begin{array}{l}\text { a. Tingkat kecepatan produksi } \\
\text { b. Jumlah produk yang dihasilkan } \\
\text { pertenaga kerja } \\
\text { c. Prosentase produk cacat } \\
\text { d. Prosentase tingkat usaha memperbaiki } \\
\text { produk cacat }\end{array}$ \\
\hline $\begin{array}{l}\text { KRITERIA BELAJAR DAN } \\
\text { PERTUMBUHAN }\end{array}$ & $\begin{array}{l}\text { a. Tingkat produktivitas karyawan } \\
\text { b. Tingkat kepuasan kerja }\end{array}$ \\
\hline
\end{tabular}

\subsection{Bobot Kepentingan Key Performance Indicator (KPI)}

Tabel 5. Bobot Kepentingan Key Performance Indicator (KPI)

\begin{tabular}{|c|l|c|}
\hline No & \multicolumn{1}{|c|}{ Indikator Kinerja } & Bobot \\
\hline 1 & Tingkat pertumbuhan penjualan & 0,395 \\
\hline 2 & Tingkat pertumbuhan pelanggan & 0,116 \\
\hline 3 & Tingkat kepuasan pelanggan & 0,077 \\
\hline 4 & $\begin{array}{l}\text { Tingkat pemenuhan keluhan } \\
\text { pelanggan }\end{array}$ & 0,039 \\
\hline 5 & Tingkat kecepatan produksi dihasilkan & 0,058 \\
\hline 6 & $\begin{array}{l}\text { Jumlah produk yang } \\
\text { pertenaga kerja }\end{array}$ & 0,058 \\
\hline 7 & Prosentase produk cacat & 0,058 \\
\hline 8 & $\begin{array}{l}\text { Prosentase tingkat usaha memperbaiki } \\
\text { produk cacat }\end{array}$ & 0,058 \\
\hline 9 & Tingkat produktivitas karyawan & 0,070 \\
\hline 10 & Tingkat kepuasan kerja & 0,070 \\
\hline
\end{tabular}

\subsection{Formula Key Performance Indicator (KPI)}

1. Tingkat pertumbuhan penjualan

$\frac{\left(\text { tingkat penjualan }_{\mathrm{t}}\right)-\left(\text { tingkat penjualan }_{\mathrm{t}-1}\right)}{\mathrm{tingkat}} \mathrm{penjulan}$ 
2. Tingkat pertumbuhan pelanggan

$\frac{\text { jml pelanggan thn }}{\mathrm{t}-\mathrm{jml} \text { pelanggan } \mathrm{thn}_{\mathrm{t}-1}} \times 100 \%$ .2

3. Tingkat kepuasan pelanggan dengan survey kepuasan pelanggan

4. Tingkat pemenuhan keluhan pelanggan

$\frac{\text { Jumlah keluhan te rlayani }}{\text { Total jumlah keluhan }} \times 100 \%$

5. Tingkat kecepatan produksi

Jumlah produk yang dihasilkan

Jam kerja terpakai 4

6. Jumlah produk yang dihasilkan pertenaga kerja

Jumlah produk yang dihasilkan

Jumlah ten aga kerja

.5

7. Prosentase produk cacat

Jumlah produk cacat

Jumlah produk yang dihasilkan

8. Prosentase tingkat usaha memperbaiki produk cacat

Jumlah produk cacat yang diperbaiki

Jumlah produk cacat yang ada

$\mathrm{x} 100 \%$ 7

9. Tingkat produktivitas karyawan

$\underline{\text { Pendapatan perusahaan (penjualan) }}$

Total jumlah karyawan

.8

10. Tingkat kepuasan kerja dengan survey Kepuasan kerja karyawan

\section{Kesimpulan}

1. Kriteria yang digunakan untuk pengukuran kinerja ada empat, yaitu: kriteria finansial, pelanggan, proses bisnis internal, belajar dan tumbuh.

2. Tujuan-tujuan strategis yang terbentuk ada 7, yaitu: pertumbuhan penjualan yang meningkat, pertumbuhan pelanggan yang tinggi, kepuasan pelanggan yang tinggi, peningkatan produktivitas, peningktan kualitas produk, produktivitas karyawan yang meningkat dan terciptanya iklim kerja yang baik 
3. KPI yang terbentuk ada $10 \mathrm{KPI}$, yaitu: tingkat pertumbuhan penjualan, tingkat pertumbuhan pelanggan, tingkat kepuasan pelanggan, tingkat pemenuhan keluhan pelanggan, tingkat kecepatan produksi, jumlah produk yang dihasilkan pertenaga kerja, persentase produk cacat, persentase tingkat usaha memperbaiki produk cacat, tingkat produktivitas karyawan, dan tingkat kepuasan kerja

\section{Ucapan Terimakasih}

Peneliti mengucapkan terimakasih kepada STTA melalui P3M yang telah mendukung penelitian ini.

\section{Daftar Pustaka}

[1] Kaplan, R. S., \& Norton, D. P. (1996). Using the balanced scorecard as a strategic management system.

[2] Mauidzoh, U., \& Zabidi, Y. (2007). Perancangan Sistem Penilaian dan Seleksi Supplier Menggunakan Multi Kriteria. Jurnal Ilmiah Teknik Industri, 5(3), 113-122.

[3] Mauidzoh, U. (2018, November). Performance Measurement of Customer Relationship Management Using Scorecard CRM (Case Study of UKM in Bayat Klaten District). In Conference SENATIK STT Adisutjipto Yogyakarta (Vol. 4, pp. 287-294).

[4] Nurdin, R., Zabidi, Y., \& Adisutjipto, S. T. T. (2005). Pengukuran Dan Analisis Produktivitas Lini Produksi PT. XYZ Dengan Menggunakan Metode Objective Matrix. Dalam Jurnal Teknik Industri Sekolah Tinggi Teknologi Adisujipto (STTA). Yogyakarta.

[5] Saaty, T. L., \& Vargas, L. G. (2012). Models, methods, concepts \& applications of the analytic hierarchy process (Vol. 175). Springer Science \& Business Media.

[6] Saaty, T. L. (2013). Analytic hierarchy process. In Encyclopedia of operations research and management science (pp. 52-64). Springer, Boston, MA.

[7] Simons, R., Russ-Eft, D., Preskill, H., Tejada, R. A., Delgado Negrini, S., Montero Corrales, M., ... \& Román, I. (2000). Performance measurement and control systems for implementing strategy (No. D10 276). IICA, Tegucigalpa (Honduras) Instituto Nacional Agrario, Tegucigalpa (Honduras) Federación de Organizaciones Privadas de Desarrollo de Honduras, Tegucigalpa (Honduras) Secretaria de Recursos Naturales, Tegucigalpa (Honduras).

[8] Zabidi, Y. (2015). Pengukuran dan Analisis Kinerja Industri Kreatif Gerabah Kasongan Bantul Guna Meningkatkan Daya Saing dan Kekuatan Daerah. Jurnal Angkasa, 7(1).

[9] Zabidi, Y., \& Suhardiwamo, S. (2016). Perancangan Sistem Standarisasi Desa Wisata Kabupaten Bantul dengan Model Sistem Pengukuran Kinerja Balanced Scorecard Guna Penguatan Industri Pariwisata Daerah. Angkasa: Jurnal Ilmiah Bidang Teknologi, 8(2), 1-8.

[10] Zabidi, Y. (2007). Perancangan Sistem Penilaian Kinerja di STT Adisutjipto sebagai Pendukung Sistem Penjaminan Mutu. Jurnal Ilmiah Teknik Industri, 5(3), 144-152.

Zabidi, Y. (2018, November). Design Of Batik Crafts Industrial Performance Measurement Model In Wukirsari Region, Bantul. In Conference SENATIK STT Adisutjipto Yogyakarta (Vol. 4, pp. 277-286). 